\title{
Aktivitas dan Kinetika Inhibisi $\alpha$-Glukosidase oleh Ekstrak Etil Asetat Umbi Lapis Bawang Merah (Allium cepa)
}

\author{
Sitaresmi Yuningtyas*, Harry Noviardi, Meita Sari Mandiri \\ ${ }^{1}$ Program Studi S1 Farmasi, Sekolah Tinggi Teknologi Industri dan Farmasi Bogor, \\ Bogor, Jawa Barat, Indonesia 16151 \\ *Email Korespondensi: sitaresmi.yuningtyas@gmail.com
}

Diterima : 6-Juli-2020

Direvisi : 24-September-2020

Disetujui : 14-Oktober-2020

Copyright @ 2020 Universitas Pakuan

FITOFARMAKA: Jurnal Ilmiah Farmasi is licensed under a

Creative Commons Attribution-ShareAlike 4.0 International License

\begin{abstract}
ABSTRAK
Hiperglikemia adalah tingginya kadar glukosa darah yang merupakan ciri dari diabetes melitus. Salah satu mekanisme obat bagi keadaan hiperglikemia adalah menghambat aktivitas a-glukosidase di dalam usus halus. Ekstrak umbi lapis bawang merah (Allium cepa) berpotensi sebagai penurun kadar glukosa darah. Penelitian ini bertujuan menentukan aktivitas inhibisi dan kinetika enzim $\alpha$-glucosidase pada ekstrak etil asetat umbi bawang merah sebagai inhibitor $\alpha$-glukosidase. Umbi lapis bawang merah diekstraksi dengan etil asetat menggunakan metode maserasi. Selanjutnya ekstrak tersebut dihitung $\mathrm{IC}_{50}$ dan aktivitas kinetika enzim $\alpha$-glukosidase. Berdasarkan hasil penelitian, diketahui bahwa ekstrak etil asetat umbi lapis bawang merah memiliki aktivitas inhibisi terhadap $\alpha$-glukosidase dengan nilai $\mathrm{IC}_{50}$ adalah $0,43 \% \mathrm{~b} / \mathrm{v}$. Ekstrak etil asetat umbi lapis bawang merah memiliki mekanisme penghambatan unkompetitif terhadap $\alpha$-glukosidase dengan parameter nilai $\mathrm{v}_{\text {maks }}$ adalah 5,862 U/mL. menit dan $\mathrm{K}_{\mathrm{M}}$ adalah 4,307 mM.
\end{abstract}

Kata kunci: Allium cepa; $\alpha$-glukosidase; hiperglikemia; inhibisi; kinetika

\section{Activity and Kinetic of $\alpha$-Glucosidase Inhibition by Ethyl Acetate Extract of Red Onion (Allium cepa) Bulbs}

\begin{abstract}
Hyperglycemia is a high level of blood glucose which is a characteristic of diabetes melitus. Inhibition of $\alpha$-glucosidase in the small intestine can reduce blood glucose levels. Red onion (Allium cepa) bulbs have reduced blood glucose levels. This study aimed to determine the activity and kinetics of the enzyme $\alpha$-glucosidase on the ethyl acetate extract of red onion (Allium cepa) bulbs as an $\alpha$-glucosidase enzyme inhibitor. Red onion bulbs were extracted with ethyl acetate using the maceration method. The extract was calculated using $I C_{50}$ and kinetics activity of $\alpha$-glucosidase enzyme. Ethyl acetate extract of red onion (Allium cepa) bulbs had inhibitory activity against $\alpha$-glucosidase with $I C_{50}$ value was $0,43 \% \mathrm{~b} / \mathrm{v}$. The ethyl acetate extract from red onion bulbs had an uncompetitive inhibition mechanism against $\alpha$ glucosidase enzyme with $v_{\max }$ value was $5.862 \mathrm{U} / \mathrm{ml}$.minute and $K_{M}$ was $4.307 \mathrm{mM}$.
\end{abstract}

Keywords: Allium cepa L; $\alpha$-glucosidase; Hyperglycemia; Inhibition; Kinetic 


\section{PENDAHULUAN}

Rendahnya hormon insulin dalam tubuh manusia dapat memicu penyakit diabetes melitus. Pada kondisi tersebut, produksi insulin oleh pankreas terbatas dan tidak sesuai kebutuhan tubuh sehingga selsel tubuh tidak dapat mengolah dan menyerap glukosa menjadi energi. Keadaan ini menyebabkan kondisi hiperglikemia dengan parameter glukosa darah diatas 180 $\mathrm{mg} / \mathrm{dL}$. Keadaan hiperglikemia ini dapat mengakibatkan kegagalan berbagai organ, terutama ginjal, saraf, mata, jantung, dan pembuluh darah (Herliana, 2013).

Pengobatan diabetes melitus untuk saat ini, yaitu dengan obat hipoglikemik oral golongan sulfonilurea. Penggunaan obat hipoglikemik memiliki efek samping yaitu gangguan saluran cerna dan gangguan susunan saraf pusat. Obat berbasis bahan alam dapat dijadikan alternatif dalam pengobatan diabetes melitus. Bahan alam yang dapat berpotensi sebagai antidiabetes salah satunya, yaitu umbi lapis bawang merah. Dosis $250 \mathrm{mg} / \mathrm{kg}$ bb dan $500 \mathrm{mg} / \mathrm{kg}$ bb dari ekstrak metanol bawang merah yang diberikan secara oral kepada tikus yang terinduksi diabetes melitus dapat meningkatkan ekspresi gen Glut4 dan Ins serta menurunkan konsentrasi glukosa darah postprandial. Selain itu, aktivitas enzim sukrase dan maltase dapat terhambat pada usus halus tikus yang terinduksi diabetes melitus setelah pemberian ekstrak tersebut (Kouhsari \& Sani, 2011). Kadar glukosa darah pada tikus yang terinduksi diabetes melitus menurun setelah diberikan jus umbi lapis bawang merah secara oral selama 14 hari. Dosis jus umbi lapis bawang merah $5000 \mathrm{mg} / \mathrm{kg}$ bb dan $10000 \mathrm{mg} / \mathrm{kg} \mathrm{bb}$ memiliki persentase penurunan kadar gula darah masing-masing sebesar $43,45 \%$ dan $59,18 \%$. Penurunan kadar gula darah dapat disebabkan oleh penghambatan penyerapan karbohidrat postprandial akibat inhibisi enzim $\alpha$-glukosidase (Luangpirom et al., 2013). Ekstrak air dan etanol dari umbi lapis bawang merah (Allium ascalonicum ) dapat menginhibisi aktivitas $\alpha$-glukosidase. Potensi inhibisi ekstrak air, etanol 70\%, dan etanol $96 \%$ terhadap enzim $\alpha$-glukosidase berturut-turut 11,75\%, 4,48\%, dan 20,92\% (Yuningtyas \& Artianti, 2015).

Berdasarkan pada hal tersebut, umbi lapis bawang merah (Allium cepa) memiliki potensi besar sebagai tanaman yang berperan sebagai penurun kadar glukosa darah. Namun kajian ilmiah mengenai ekstrak etil asetat umbi lapis bawang merah sebagai agen antidiabetes belum ada. Penelitian ini bertujuan menentukan aktivitas dan mekanisme inhibisi ekstrak etil asetat umbi lapis bawang merah terhadap enzim $\alpha$-glukosidase. Mekanisme inhibisi tersebut dilakukan dengan penentuan kinetika enzim.

\section{METODE PENELITIAN}

\section{Alat dan Bahan}

Alat yang digunakan adalah peralatan gelas, microplate (Thermo Scientific NUNC), perangkat instrumen microplate reader (Epoch Microplate Spectrophotometer), penguap putar (rotary evaporator) (BUCHI R-250), dan micropipet (Thermo Scientific).

Bahan tanaman yang digunakan adalah umbi lapis bawang merah (Allium cepa L) berumur 2 bulan 10 hari yang berasal dari perkebunan di daerah Brebes, Jawa tengah dan telah dideterminasi oleh Herbarium Bogoriense, Pusat Penelitian Biologi, Lembaga Ilmu Pengetahuan Indonesia (LIPI). Selain itu, bahan yang digunakan adalah pelarut etil asetat, aquades, serbuk magnesium $(\mathrm{Mg})$, pereaksi Mayer, pereaksi Wagner, pereaksi Dragendorf, $\mathrm{HCl}$, amil alkohol, $\mathrm{H}_{2} \mathrm{SO}_{4} \mathrm{p}$, $\mathrm{FeCl}_{3}$, kloroform, asam asetat anhidrat, buffer fosfat $\mathrm{pH} \mathrm{7,} \mathrm{dimetil} \mathrm{sulfoksida}$ (DMSO), larutan $\mathrm{Na}_{2} \mathrm{CO}_{3}, \alpha$-glukosidase (Sigma G3651-250UN), p-nitrofenol (Sigma) dan substrat p-nitrofenil $\alpha$-Dglukopiranosa (pNPG) (Sigma N1337-5G). 


\section{Ekstraksi Umbi Lapis Bawang Merah}

Sebanyak 50 gram serbuk simplisia umbi lapis bawang merah dimaserasi dengan $100 \mathrm{~mL}$ etil asetat selama 24 jam pada suhu kamar di dalam botol kaca gelap. Hasil maserasi disaring dan filtratnya disimpan. Residu dilakukan remaserasi dengan pelarut yang sama. Remaserasi dilakukan sebanyak dua kali sehingga total ekstraksi selama $3 \times 24$ jam. Filtrat dipekatkan dengan penguap putar (rotary evaporator) pada suhu $60{ }^{\circ} \mathrm{C}$ hingga terbentuk ekstrak kental \% (Yuningtyas \& Artianti, 2015). Rendemen ekstrak yang diperoleh, dihitung dengan rumus sebagai berikut.

Rendemen $(\%)=\frac{\text { bobot ekstrak }(\mathrm{g})}{\text { bobot simplisia }(\mathrm{g})} \times 100 \%$

Selanjutnya ekstrak etil asetat umbi lapis bawang merah dilakukan analisis fitokimia, penentuan nilai $\mathrm{IC}_{50}$ dan penentuan kinetika enzim $\alpha$-glukosidase.

\section{Penapisan Fitokimia}

Pembuatan larutan uji untuk penapisan fitokimia dengan melarutkan 500 mg ekstrak etil asetat umbi lapis bawang merah dengan $50 \mathrm{~mL}$ DMSO kemudian dilakukan uji fitokimia berupa uji kualitatif golongan senyawa flavonoid, alkaloid, tanin, saponin, terpenoid, dan steroid (Velavan, 2015).

\section{Uji Alkaloid}

Sebanyak $5 \mathrm{~mL}$ dimasukkan dalam tabung reaksi lalu ditambahkan $1 \mathrm{~mL}$ asam klorida $2 \mathrm{~N}$ dan $10 \mathrm{~mL}$ air kemudian dipanaskan di penangas air selama 2 menit lalu didinginkan dan disaring. Filtrat dibagi menjadi 3 tabung reaksi. Pada tabung pertama dimasukkan pereaksi Mayer, pada tabung kedua dimasukkan pereaksi Dragendorff, dan pada tabung ketiga dimasukkan pereaksi Wagner. Jika terbentuk endapan putih pada tabung pertama, terbentuk endapan merah jingga pada tabung kedua, dan terbentuk endapan coklat pada tabung ketiga maka menandakan adanya alkaloid.

\section{Uji Flavonoid}

Sebanyak $5 \mathrm{~mL}$ sampel dipanaskan selama 5 menit setelah itu disaring. Filtrat ditambahkan serbuk magnesium serta HCl:etanol (1:1) dan amil alkohol. Hasil dinyatakan positif bila terbentuk endapan warna jingga hingga merah ungu.

\section{Uji Saponin}

Sebanyak $5 \mathrm{~mL}$ sampel dimasukkan ke dalam tabung reaksi kemudian dikocok kuat-kuat. Adanya saponin ditandai dengan terbentuk busa yang stabil.

\section{Uji Tanin}

Sebanyak $5 \mathrm{~mL}$ sampel ditetesi $\mathrm{FeCl}_{3}$ 1\%. Adanya tanin ditandai dengan munculnya warna hijau kecoklatan atau biru kehitaman.

\section{Uji Steroid}

Sebanyak $5 \mathrm{~mL}$ diuapkan dalam cawan penguap. Residu dilarutkan dengan $0,5 \mathrm{~mL}$ kloroform, ditambahkan $0,5 \mathrm{~mL}$ asam asetat anhidrat, dan $2 \mathrm{~mL}$ asam sulfat pekat melalui dinding tabung. Terbentuknya cincin coklat atau violet pada perbatasan larutan menunjukkan adanya triterpenoid, sedangkan bila muncul cincin biru kehijauan menunjukkan adanya steroid.

\section{Penentuan Aktivitas Inhibisi a- Glukosidase Oleh Ekstrak Etil Asetat Umbi Lapis Bawang Merah}

Sebanyak $0,5 \mathrm{mg}$ enzim $\alpha$ Glukosidase dilarutkan dengan buffer fosfat $0,1 \mathrm{M} \mathrm{pH} 7$ yang mengandung $100 \mathrm{mg}$ BSA (Bovine Serum Albumin). Sebanyak $500 \mu \mathrm{L}$ $p$-nitrofenil- $\alpha$-D-glukopiranosida (substrat) $20 \mathrm{mM}, 980 \mu \mathrm{L}$ buffer fosfat $0,1 \mathrm{M} \mathrm{pH}$ 7, 20 $\mu \mathrm{L}$ ekstrak etil asetat umbi lapis bawang merah dengan konsentrasi $0,1 \% ; 0,25 \%$; $0,50 \% ; 1 \%$; dan $2 \% \mathrm{~b} / \mathrm{v}$ dalam DMSO (dimethyl sulfoxide) serta $500 \mu \mathrm{L}$ enzim 
dimasukkan dalam microplate. Campuran reaksi diinkubasi suhu $37{ }^{\circ} \mathrm{C}$ selama 15 menit. Reaksi dihentikan dengan penambahan $2 \mathrm{~mL} \mathrm{Na} \mathrm{CO}_{3} 200 \mathrm{mM}$ dan diukur serapan pada panjang gelombang 400 nm (Modifikasi metode Sancheti et.al., 2009). Persentase daya inhibisi dihitung dengan persamaan sebagai berikut.

Daya Inhibisi $(\%)=\frac{\text { Absorbansi kontrol-Absorbansi ekstrak }}{\text { Absorbansi kontrol }} \times 100 \%$

Persentase aktivitas daya inhibisi $\alpha$ Glukosidase yang diperoleh digunakan untuk penentuan nilai $\mathrm{IC}_{50}$ (Inhibition Concentration 50).

\section{Penentuan Kinetika Inhibisi Enzim}

Pembuatan kurva standar terlebih dahulu dilakukan dengan menggunakan larutan $p$-nitrofenol $(p \mathrm{NP})$ dengan konsentrasi 25, 50, 75, $100 \mathrm{mM}$. Larutan blanko menggunakan larutan buffer fosfat $0,1 \mathrm{M} \mathrm{pH}$ 7. Serapannya diukur pada panjang gelombang $400 \mathrm{~nm}$. Pengukuran dilakukan triplo.

Analisis kinetika inhibisi menggunakan dua sistem reaksi, yaitu substrat dengan konsentrasi berbeda $(5,10$, $15,20,25 \mathrm{mM}$ ) dicampurkan dengan enzim dan yang kedua menggunakan ekstrak etil asetat umbi lapis bawang merah sebagai inhibitor (konsentrasi berdasarkan nilai $\mathrm{IC}_{50}$ ). Metode pengerjaan mengacu pada metode aktivitas ekstrak etil asetat umbi lapis bawang merah sebagai inhibitor $\alpha$ glukosidase (modifikasi metode Sancheti, et.al., 2009). Kecepatan reaksi (v) diukur sebagai kecepatan pembentukan produk persatuan waktu dan ditentukan menggunakan rumus berikut.

$\mathrm{V}=\frac{[p \mathrm{NP}]}{\mathrm{V} \times \mathrm{t}}$

Keterangan :

$\mathrm{v} \quad$ : kecepatan reaksi enzim (U/ml menit)

$[p \mathrm{NP}]$ : konsentrasi p-nitrofenol yang terbentuk (mM)

$\mathrm{V} \quad$ : volume enzim dalam sistem reaksi (ml)

$\mathrm{T} \quad$ : waktu inkubasi (menit)
Penentuan jenis inhibisi dari ekstrak etil asetat umbi lapis bawang merah dengan cara membuat grafik Lineweaver-Burk dengan memplot $1 /[\mathrm{S}]$ sebagai sumbu $\mathrm{x}$ dan $1 / \mathrm{v}$ sebagai sumbu $\mathrm{y}$ sehingga dapat diperoleh nilai $\mathrm{K}_{\mathrm{M}}$ (Konstanta Michaelis Menten dan $\mathrm{V}_{\text {maks }}$ (kecepatan maksimum). Persamaan grafik Lineweaver-Burk sebagai berikut.

$\frac{1}{\mathrm{v}}=\frac{\mathrm{K}_{\mathrm{M}}}{\mathrm{v}_{\text {maks }}} \cdot \frac{1}{[\mathrm{~S}]}+\frac{1}{\mathrm{v}_{\text {maks }}}$

Perlakuan tanpa inhibitor dan dengan inhibitor dibuat Grafik Lineweaver-Burk kemudian dibandingkan. Menurut Nelson, et. al., (2005), jika nilai $\mathrm{v}_{\text {maks }}$ keduanya sama maka jenis inhibisi ekstrak tersebut adalah inhibitor kompetitif. Jika nilai $\mathrm{K}_{\mathrm{M}}$ keduanya sama maka jenis inhibisi ekstrak tersebut adalah inhibitor nonkompetitif. Jika nilai $\mathrm{K}_{\mathrm{M}}$ dan $\mathrm{v}_{\text {maks }}$ keduanya berbeda maka jenis inhibisi ekstrak tersebut adalah inhibitor unkompetitif.

\section{Analisis Data}

Nilai $\mathrm{IC}_{50}$ dari ekstrak etil asetat umbi lapis bawang merah ditentukan dengan membuat regresi linear antara data persentase daya inhibisi dan konsentrasi ekstrak. Penentuan jenis inhibisi dari ekstrak tersebut dengan cara membuat grafik Lineweaver-Burk untuk menentukan nilai $\mathrm{K}_{\mathrm{M}}$ dan $\mathrm{v}_{\text {maks. }}$.

\section{HASIL DAN PEMBAHASAN Karakteristik Simplisia}

Proses ekstraksi umbi lapis bawang merah menggunakan pelarut etil asetat dengan metode maserasi. Pemilihan etil 
asetat sebagai pelarut karena kepolarannya yang relatif rendah atau semi polar sehingga mampu menyari senyawa golongan aglikon maupun glikon (Velavan, 2015). Ekstrak etil asetat umbi lapis bawang merah yang diperoleh adalah 2,961 gram sehingga rendemennya sebesar 5,92\%. Yuningtyas dan Artianti (2015), menyatakan ekstrak air, etanol $70 \%$, dan etanol $96 \%$ dari umbi lapis bawang merah berturut-turut sebesar $38,27 \%$, 27,49\%, dan 15,35\%. Perbedaan rendemen tersebut disebabkan polaritas dari pelarut yang dipakai sehingga menyebabkan perbedaan komponen senyawa kimia yang tersari.

\section{Penapisan Fitokimia}

Golongan senyawa flavonoid, saponin, dan tanin terdapat pada ekstrak etil asetat umbi lapis bawang merah. Rentang polaritas yang lebar dari etil asetat sehingga dapat menarik senyawa-senyawa polar hingga semipolar. Gugus hidroksil yang tidak tersubstitusi dimiliki oleh flavonoid sehingga flavonoid bersifat polar. Tanin bersifat polar karena termasuk golongan polifenol. Saponin bersifat polar karena memiliki gugus glikosil (Velavan, 2015). Ketiga jenis senyawa tersebut memiliki aktivitas inhibisi terhadap $\alpha$-glukosidase. Kerja $\alpha$-glukosidase dapat dihambat oleh senyawa fitokimia seperti golongan flavonoid (Wang \& Song, 2010), golongan alkaloid (Patel \& Mishra, 2012), tanin (Lee et al., 2017), saponin, dan triterpenoid (Lai et al., 2012).

\section{Aktivitas Inhibisi Ekstrak Etil Asetat Umbi Lapis Bawang Merah Terhadap $\alpha$ - Glukosidase}

Kemampuan potensial ekstrak etil asetat umbi lapis bawang merah sebagai agen hipoglikemik diuji secara in vitro melalui inhibisi aktivitas $\alpha$-glukosidase.
Pada Gambar 1 menunjukkan bahwa ekstrak etil asetat umbi lapis bawang merah mempunyai kemampuan untuk menghambat aktivitas $\alpha$-glukosidase. Konsentrasi ekstrak etil asetat umbi lapis bawang merah terbesar $(2 \% \mathrm{~b} / \mathrm{v})$ memiliki persentase daya inhibisi sebesar $85,18 \%$. Daya inhibisi terkecil dimiliki konsentrasi $0,1 \% \mathrm{~b} / \mathrm{v}$, yaitu $12,15 \%$. Oleh karena itu, nilai $\mathrm{IC}_{50}$ dari ekstrak etil asetat umbi lapis bawang merah sebesar $0,43 \% \mathrm{~b} / \mathrm{v}$ artinya ekstrak tersebut sudah menghambat kerja $\alpha$ glukosidase sebesar 50\% pada konsentrasi $0,43 \%$ b/v. Yuningtyas dan Artianti (2015) menyatakan daya inhibisi $\alpha$-glukosidase oleh ekstrak air, ekstrak etanol $70 \%$, dan ekstrak etanol $96 \%$ umbi lapis bawang merah (A. ascalonicum) 1\% (b/v) berturutturut sebesar $11,75 \%, 4,48 \%$, dan 20,92\%. Daya inhibisi ekstrak etil asetat umbi lapis bawang merah lebih tinggi dibandingkan dengan daya inhibisi dari ekstrak air dan etanol umbi lapis bawang merah ( $A$. ascalonicum). Perbedaan daya inhibisi ini disebabkan perbedaan komponen golongan senyawa kimia yang tersari. Ekstrak etil asetat umbi lapis bawang merah mengandung flavonoid, saponin, dan tanin.

Cara kerja enzim $\alpha$-glukosidase adalah memotong ikatan glikosida pada oligosakarida. Aktivitas $\alpha$-glukosidase berperan dalam hidrolisis polisakarida menjadi monosakarida. Proses ini bertujuan agar monosakarida yaitu glukosa dapat diserap oleh tubuh. Oleh karena itu, mekanisme inhibisi $\alpha$-glukosidase dapat mengatasi kondisi hiperglikemia. Hal ini disebabkan jumlah monosakarida yang dapat diserap usus menjadi berkurang. Inhibitor $\alpha$-glukosidase sebagian besar bekerja dengan cara meniru posisi transisi unit piranodisik dari substrat $\alpha$-glukosidase alami (Lankatillake, et. al., 2019). 


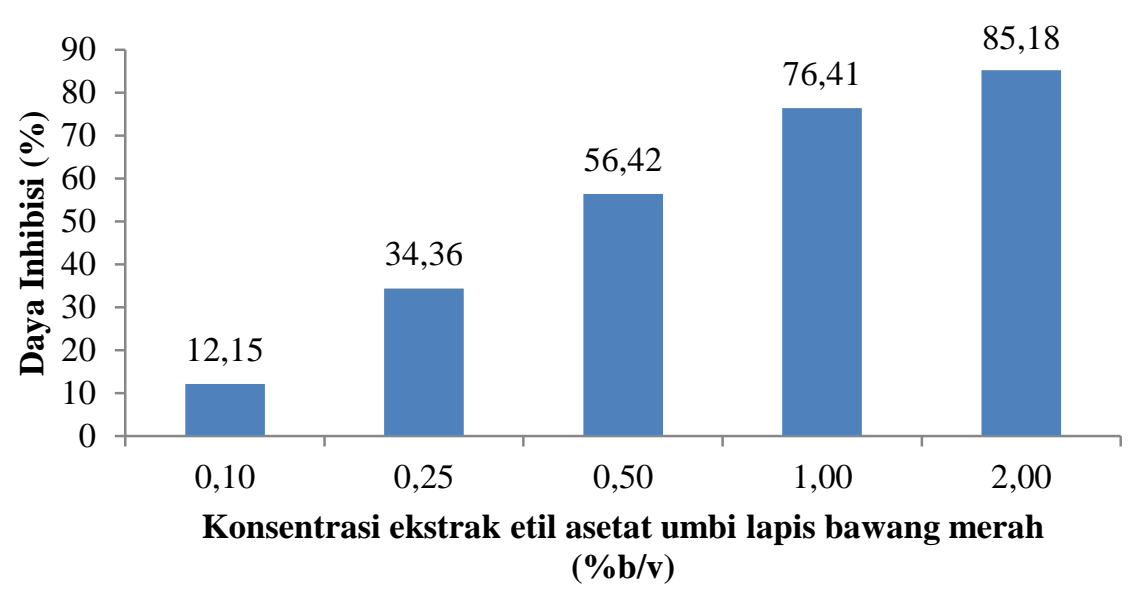

Gambar 1. Daya inhibisi $\alpha$-glukosidase ekstrak etil asetat umbi lapis bawang merah

Kemampuan ekstrak etil asetat umbi lapis bawang merah dalam menginhibisi $\alpha$ glukosidase tidak lepas dari senyawa yang dikandungnya yaitu flavonoid, saponin, dan tanin. Golongan senyawa tersebut memiliki aktivitas hipoglikemik atau penurun kadar glukosa darah dengan menghambat enzimenzim penting yang berperan dalam pemecahan karbohidrat menjadi monosakarida yang dapat diabsorbsi oleh usus halus, yaitu enzim $\alpha$-amilase dan enzim $\alpha$-glukosidase. Penghambatan pada kedua enzim tersebut berakibat terganggunya proses pemecahan karbohidrat menjadi monosakarida sehingga tidak dapat diserap oleh usus. Dengan demikian, kadar glukosa darah tidak meningkat setelah mengkonsumsi makanan yang mengandung glukosa (Lankatillake, et.al., 2019). Yuningtyas dan Artianti (2015) menyatakan ekstrak air dari umbi lapis bawang merah (A. ascalonicum) dapat menginhibisi $\alpha$ glukosidase karena mengandung flavonoid dan tanin. Selain itu, ekstrak etanol umbi lapis bawang merah (A. ascalonicum) mengandung flavonoid, saponin, dan tanin juga dapat menginhibisi aktivitas $\alpha$ glukosidase.

\section{Kinetika dan Jenis Inhibisi Dari Ekstrak Umbi Lapis Bawang Merah}

Penentuan kinetika enzim adalah untuk menentukan mekanisme kerja enzim dan perannya dalam proses metabolisme, cara kerja enzim, dan mekanisme obat yang dapat menghambat enzim. Parameter yang ditentukan dalam kinetika enzim ini adalah $\mathrm{K}_{\mathrm{M}}$ (Konstanta Michaelis-Menten) dan $\mathrm{v}_{\text {maks }}$ (kecepatan reaksi maksimum). Penentuan parameter ini dapat dilakukan dengan membuat plot hubungan antara laju reaksi enzim (v) dan konsentrasi substrat [S]. Laju reaksi enzim semakin meningkat secara linear terhadap konsentrasi substrat, lalu mulai konstan hingga konsentrasi substrat tertentu. Keadaan laju reaksi enzim tidak dapat naik lagi disebut kecepatan maksimum atau $\mathrm{v}_{\text {maks. }}$. Jenis inhibisi ekstrak tersebut perlu diketahui untuk mengetahui karakteristik dari inhibitor dengan menentukan nilai kecepatan reaksi maksimum ( $\mathrm{v}_{\text {maks }}$ ) dan konstanta MichaelisMenten $\left(\mathrm{K}_{\mathrm{M}}\right)$. Nilai $\mathrm{V}_{\text {maks }}$ menunjukkan tingkat kejenuhan reaksi antara enzim oleh substrat. Sedangkan nilai $\mathrm{K}_{\mathrm{M}}$ adalah konsentrasi substrat tertentu pada saat kecepatan katalitik enzim mencapai setengah kecepatan maksimumnya. Nilai tersebut menunjukan tingkat efisiensi katalisis dari enzim (Nelson, et. al. , 2005).

Nilai $K_{M}$ dan $v_{\text {maks }}$ ditentukan dengan cara mengukur kecepatan reaksi enzim dengan berbagai variasi konsentrasi substrat yaitu $5 \mathrm{mM} ; 10 \mathrm{mM} ; 15 \mathrm{mM} ; 20 \mathrm{mM} ; 25$ 
mM. Pada Gambar 2, dapat dilihat hubungan antara konsentrasi substrat dengan kecepatan reaksi enzim $\alpha$-glukosidase. Berdasarkan teori kinetika enzim, semakin meningkatnya konsentrasi substrat maka semakin meningkat pula energi serta frekuensi benturan antar molekul. Hal ini menyebabkan semakin banyak enzim $\alpha$ glukosidase yang dapat menghidrolisis substrat sehingga menghasilkan produk (Nelson, et. al., 2005). Berdasarkan Gambar 2, peningkatan konsentrasi substrat dapat meningkatkan aktivitas enzim. Kecepatan enzim tanpa inhibitor memiliki nilai yang lebih tinggi dibandingkan kecepatan enzim dengan inhibitor (ekstrak etil asetat umbi lapis bawang merah). Hal ini disebabkan enzim lebih mudah bereaksi jika tanpa adanya inhibitor sehingga kecepatan reaksi pun lebih tinggi. Meskipun demikian, peningkatan aktivitas enzim akan terhenti jika enzim sudah jenuh dengan substrat karena jumlah substrat sudah melampaui jumlah enzim setelah titik batas laju kecepatan maksimum $\left(\mathrm{v}_{\text {maks }}\right)$ dari reaksi enzimatis.

Nilai $v_{\text {maks }}$ dan $K_{M}$ dapat ditentukan dengan mentransformasikan persamaan Michaelis-Menten ke dalam persamaan Lineweaver-Burk (Gambar 3). Berdasarkan Gambar 3, diperoleh persamaan linear untuk sampel tanpa inhibitor (enzim dan substrat) $\mathrm{y}=0,781 \mathrm{x}+0,162$, sehingga nilai $\mathrm{v}_{\text {maks }}$ sebesar 6,173 U/mL.menit dan $\mathrm{K}_{\mathrm{M}}$ sebesar $4,821 \mathrm{mM}$. Nilai $\mathrm{v}_{\text {maks }}$ sebesar 6,173 U/mL.menit menunjukkan kecepatan maksimum $\alpha$-glukosidase dalam mengubah substrat pNPG menjadi pNP dan glukosa sebesar 6,173 Unit per menitnya, sedangkan konstanta Michaelis Menten $\left(\mathrm{K}_{\mathrm{M}}\right)$ ketika enzim $\alpha$-glukosidase mencapai setengah dari kecepatan maksimumnya adalah sebesar $4,821 \mathrm{mM}$.

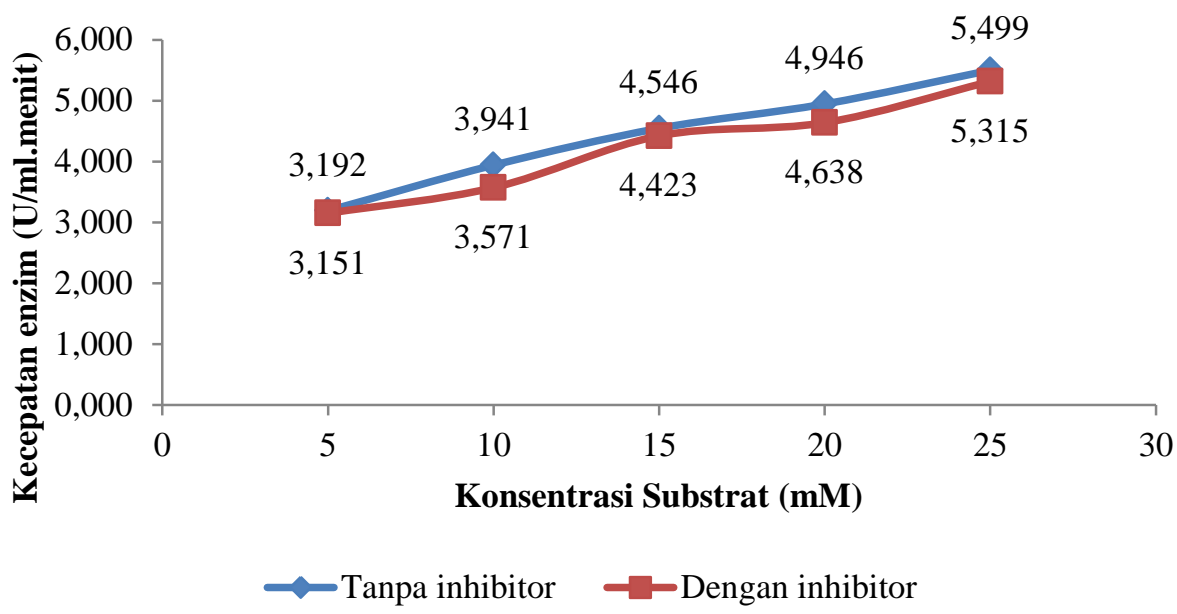

Gambar 2. Hubungan Kecepatan Reaksi Enzim $\alpha$-glukosidase Terhadap Konsentrasi Substrat 


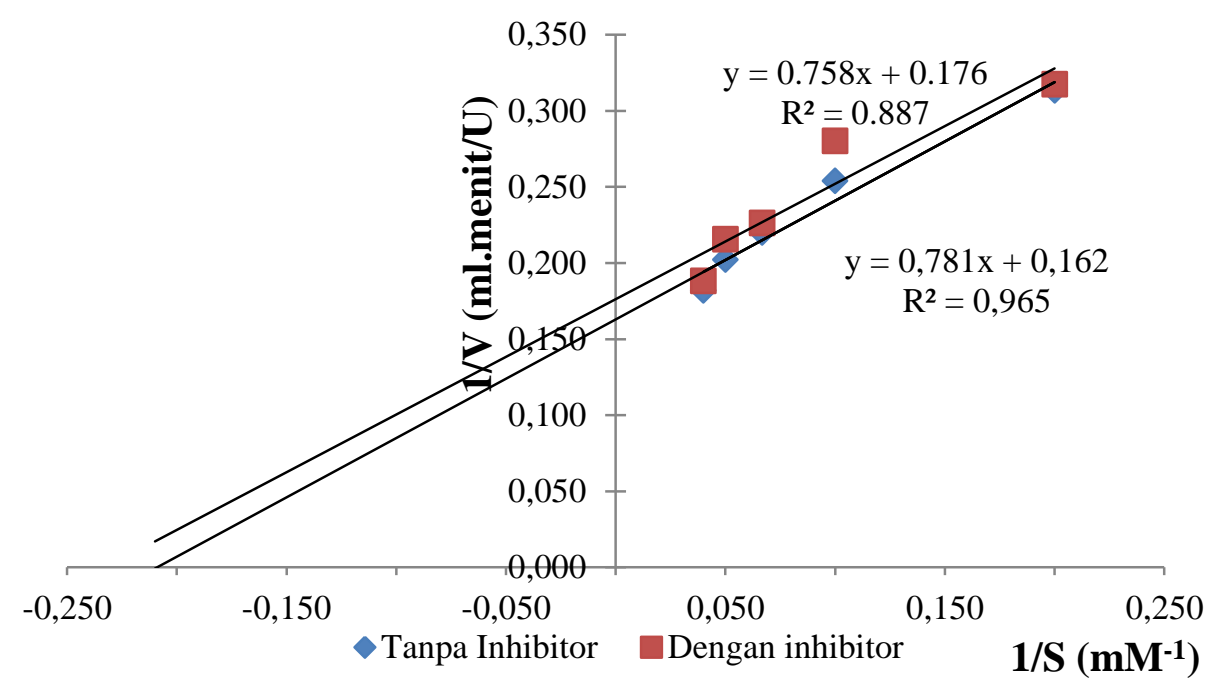

Gambar 3. Kinetika Reaksi Enzim $\alpha$-glukosidase.

Persamaan linear untuk sampel dengan inhibitor (enzim, substrat, dan ekstrak umbi lapis bawang merah) yaitu $\mathrm{y}=$ $0,758 \mathrm{x}+0,176$, sehingga nilai $\mathrm{v}_{\text {maks }}$ sebesar 5,682 U/mL.menit dan $\mathrm{K}_{\mathrm{M}}$ sebesar 4,307 $\mathrm{mM}$. Nilai $\mathrm{v}_{\text {maks }} \alpha$-glukosidase dengan inhibitor sebesar 5,682 U/mL.menit menunjukkan kecepatan maksimum enzim $\alpha$-glukosidase dalam mengubah substrat pNPG menjadi pNP dan glukosa sebesar 5,682 Unit per menitnya, sedangkan konstanta Michaelis-Menten ketika enzim $\alpha$ glukosidase mencapai setengah dari kecepatan maksimumnya adalah sebesar 4,307 $\mathrm{mM}$.

Tabel 1. Nilai Kinetika Reaksi Enzim $\alpha$ glukosidase

\begin{tabular}{lcc}
\hline Sampel & $\begin{array}{c}\mathbf{K}_{\mathbf{M}} \\
(\mathbf{m M})\end{array}$ & $\begin{array}{c}\mathbf{v}_{\text {maks }} \\
(\mathbf{U} / \mathbf{m l} \text {. menit })\end{array}$ \\
\hline Tanpa Inhibitor & 4,821 & 6,173 \\
Dengan Inhibitor & 4,307 & 5,682 \\
\hline
\end{tabular}

Berdasarkan data pada Tabel 1, jenis inhibisi ekstrak etil asetat umbi lapis bawang merah adalah inhibisi unkompetitif. Nelson, et.al., (2005) menyatakan jika nilai $\mathrm{K}_{\mathrm{M}}$ dan $\mathrm{V}_{\text {maks }}$ enzim tanpa inhibitor itu berbeda dengan nilai $K_{M}$ dan $v_{\text {maks }}$ enzim dengan inhibitor maka jenis penghambatannya termasuk inhibisi unkompetitif. Pada jenis inhibisi unkompetitif, sisi alosterik enzim masih dapat mengikat inhibitor walaupun sudah terbentuk kompleks enzim-substrat. Pada jenis inhibisi ini, inhibitor hanya dapat terikat jika telah terbentuk kompleks enzimsubstrat. Akibat terbentuk kompleks enzimsubstrat-inhibitor, sifat katalisator dari enzim akan hilang dan tidak akan terbentuk produk. Produk hanya akan terbentuk, jika inhibitor terlepas dari kompleks enzimsubstrat-inhibitor. Inhibisi unkompetitif dapat terjadi akibat adanya akumulasi produk dari reaksi enzim-substrat (Nelson, et.al., 2005). Mekanisme penghambatan ekstrak etil asetat umbi lapis bawang merah terhadap $\alpha$-glukosidase adalah jenis inhibisi unkompetitif. Hal ini adalah terjadinya penurunan nilai $\mathrm{K}_{\mathrm{M}}$ dan $\mathrm{v}_{\text {maks }}$ dari keadaan normalnya.

\section{KESIMPULAN DAN SARAN Kesimpulan}

Ekstrak etil asetat umbi lapis bawang merah (Allium cepa) memiliki potensi inhibisi terhadap aktivitas $\alpha$-glukosidase dengan nilai $\mathrm{IC}_{50}$ sebesar $0,43 \% \mathrm{~b} / \mathrm{v}$. Ekstrak etil asetat umbi lapis bawang merah memiliki mekanisme inhibisi unkompetitif terhadap enzim $\alpha$ glukosidase dengan parameter nilai $\mathrm{v}_{\text {maks }}$ sebesar 5,682 U/mL.menit dan $\mathrm{K}_{\mathrm{M}}$ sebesar 4,307 mM.

\section{Saran}

Senyawa spesifik pada ekstrak etil asetat umbi lapis bawang merah yang 
berperan dalam inhibisi aktivitas enzim $\alpha$ glukosidase perlu ditelusuri lebih lanjut.

\section{UCAPAN TERIMA KASIH}

Penulis mengucapkan terima kasih kepada Lembaga Penelitian dan Pengabdian Masyarakat (LPPM) STTIF Bogor yang telah mendukung terlaksananya penelitian ini.

\section{DAFTAR PUSTAKA}

Herliana, E. (2013). Diabetes Kandas Berkat Herbal. Jakarta: Fmedia.

Lai, Y.C., Chen, C.K., Tsai, S.F., Lee, S.S. (2012). Triterpenes as $\alpha$-glucosidase inhibitors from Fagus hayatae. Phytochemistry. 74: 206-211.

Lankatillake, C., Huynh, T., Dias, D.A. (2019). Review: Understanding glycaemic control and current approaches for screening antidiabetic natural products from evidence-based medicinal plants. Plant Methods. 15(1): 1-35.

Lee, D.Y., Kim, H.W., Yang, H., Sung, S.H. (2017). Hydrolyzable tannins from the fruits of Terminalia chebula Retz and their $\alpha$-glucosidase inhibitory activities. Phytochemistry. 137: 109116.

Luangpirom, A., Kourchampa, W., Junaimuang, T., Somsapt, P., Sritagool, O. (2013). Effect of shallot (Allium ascalonicum L.) bulb juice on hypoglycemia and sperm quality in streptozotocin induced diabetic mice.
ABAH Bioflux 5 (1): 49

Montasser K. S., Fehresty S. M. (2011). Antidiabetic effects of Allium ascalonicum methanolic extract in experimental diabetes. Planta Medica. 77 (12): 87. http://www.thiemeconnect.de/DOI/DOI?10.1055/s0031-1282475

Nelson, D.L., Albert, L.L., Michael, M.C. (2005). Lehninger Principles of Biochemistry. W.H. Freeman: Portland.

Patel, M. B., Mishra, S. M. (2012). Magnoflorine from Tinospora cordifolia stem inhibits $\alpha$-glucosidase and is antiglycemic in rats. Journal of Functional Foods. 4(1): 79-86.

Sancheti, S., Sancheti, S., Seo, S.Y. (2009). Chaenomeles sinensis: A potent $\alpha$-and $\beta$-glucosidase inhibitor. American Journal of Pharmacology and Toxicology, 4(1): 8-11.

Velavan, S. (2015). Phytochemical Techniques-A Review. World Journal of Science and Research, 1(2): 80-91.

Wang, H., Du, Y.J., Song, H.C. (2010). $\alpha-$ Glucosidase and $\alpha$-amylase inhibitory activities of guava leaves. Food Chemistry, 123(1): 6-13.

Yuningtyas, S., Artianti, D.S. (2015). Aktivitas Inhibisi Enzim $\alpha$ Glukosidase Ekstrak Air Dan Etanol Umbi Lapis Bawang Merah (Allium ascalonicum). Fitofarmaka: Jurnal Ilmiah Farmasi 5(1): 1-7. 